\title{
A comparative study of DGNB, LEED and BREEAM certificate systems in urban sustainability
}

\author{
A. Zeinal Hamedani \& F. Huber \\ Bergische Universität Wuppertal, Germany
}

\begin{abstract}
Certification systems are generally used for the purpose of sustainability assessment in buildings or neighbourhoods, and indexes mainly focus on construction issues related to the civil engineering activities but not usually in urban management programs. As an attempt to tackle this issue, the "German Sustainable Building Council" has created and developed a certification system according to the three aspects of economical, ecological and social culture in planning, construction, and operation of buildings in Germany. This paper focuses on the brief history and introduction of these three kinds of certification systems named as DGNB, LEED and BREEAM. The certification process, certification types, their criteria and rating system are all reviewed in five sections of this paper. Finally the results of analysis and comparison of these systems along with the advantages and disadvantages of them which will be helpful for assessment of two main subjects of "sustainable urban development strategies" and "tools for sustainability assessment in urban communities" are discussed. As a conclusion it is shown that certification systems are quantitative standards to measure the concept of sustainable development in any region. By defining a set of criteria and a rating system to score them, these systems assess projects during a specific process. The result of this assessment can be useful for different groups, e.g. national and local governments, users, planners, builders, owners, investors, etc. It can be concluded that identifying comprehensive objectives, adopting proper strategies to realize those objectives, applying certification systems to control the performed activities, and correcting the objectives and strategies will definitely guarantee sustainable development achievements.
\end{abstract}

Keywords: sustainable development, certificate system, DGNB, LEED, BREEAM. 


\section{Introduction}

The concept of sustainable development was seriously taken up in the early $90 \mathrm{~s}$ and has since developed in most of scientific and industrial branches. Since the arrival of this concept, various definitions have been offered and different methods have been applied for realizing this concept.

Apart from the diverse definitions, sustainable development has three major aspects which are environmental, economic, and social. Since all these three aspects are mainly defined and examined within the framework of cities (as a place of residence, work, education, and people's social activities), sustainable urban development has become the principal element to achieve sustainability.

As a result of rapid international changes in all aspects, environmental (e.g. global and local climate changes), economic (e.g. economic crises), and social (e.g. demographic changes), adopting effective strategies for sustainable urban development, and creating and developing efficient mechanisms for sustainability assessment and strategy improvement are among the primary subjects at regional, national, and global levels.

This paper therefore focuses on certification systems as the tools for assessing and measuring sustainability which has been specifically offered for urban sustainability. The outline of the rest of this paper is as follows. In section two we study the three well-known certification systems, namely BREEAM Communities, LEED-ND, and DGNB-NSQ. Section three compares the above certificate systems using rating system, certificate process and criteria. Finally, section four concludes the paper.

\section{Certification systems for sustainable urbanism}

\subsection{Definition and purposes}

Today, sustainability has become an influential concept in economic, social, and other policies of developed countries.

In addition, cities and city districts (as the base of sustainable development) have such a stronger role in the advancement of sustainable urban development that sustainable development in districts is the precondition for the realization of sustainable development at higher levels.

In the figure 1, a mutual relationship can be seen between the first level and the last level. This relationship can be explained as follow:

Determine the general objectives and main aspects of sustainable development at national and international levels, and also details and small objectives at regional and urban levels (TOP-DOWN).

Determine functional strategies and executive projects at regional and local levels; supporting and monitoring at national and international levels (BOTTOM-UP).

The important point is that a tool is required to evaluate the objectives and strategies of sustainable urban development. This need has resulted in the emergence and spread of certification systems. 


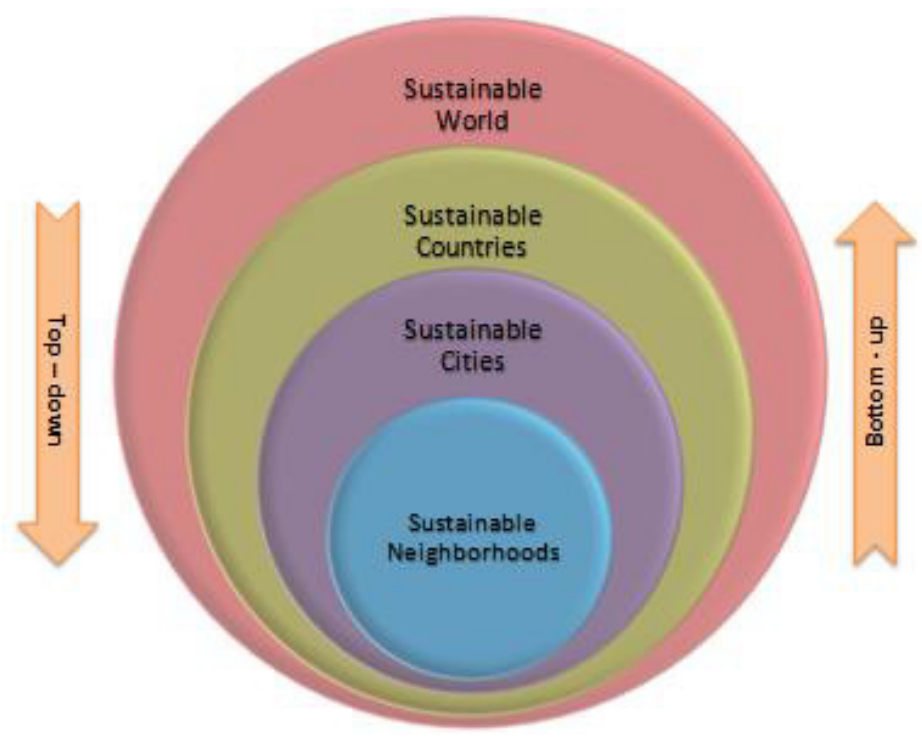

Figure 1: The use of the top-down and bottom-up method for sustainable urban development [1].

Considering the variety of objectives, strategies, and practical approaches of sustainable development at different levels and in different areas, it can be stated that "certification systems" are a tool to assess these objectives and approaches. In other words, they are a quantitative standard to measure the concept of sustainable development in each area.

These systems can be employed in buildings that have different occupancies and in sustainable urban development projects. However, these certificates are different from building codes of practice. The codes show the minimum requirements for development and construction, whereas certificates rate buildings and projects according to quality and predefined criteria, and they can show the maximum.

The following items can be pointed out in the definition of certification systems:

Define criteria and indicators: this is the main element in these systems.

Criterion: states the main specifications and details of the determined objectives (i.e. objectives and aspects of sustainable urban development).

Indicator: quantitative and measurable description of the criteria. Each criterion might be evaluated by a number of indicators [2].

Rating system: shows the specific boundaries of classification. Also, the evaluation method (quantitative or qualitative) for indicators measurement, the criteria importance factor, and the minimum level of requirement must be carefully identified in this part. Finally, the result of evaluation must be shown simply and specifically.

Certification process: decides the necessary measures and the steps to award the certificate. Assessment and rating usually takes place in a number of building 
(or city quarter) life cycle phases (e.g. design and planning, construction, etc.). It has to be taken into account that the assessment process and what is observed in which phase must be explained in detail.

Besides, the assessing people or organizations, the applied instruments and standards, and the documents required for assessment must be specified.

Certification systems are categorized based on the evaluation subject (house building, office building, neighbourhood, etc.). They first appeared with the aim of sustainability assessment in buildings, yet in recent years a lot of attention has been given to sustainability assessment in neighbourhoods. More and more attention to the importance and influence of cities and districts, climate changes, demographic changes, and economic crisis can be one of the reasons. Moreover, neighbourhood, as the level between city and building, is the smallest detail that contains all the aspects and criteria for sustainable urban development. As a result, the realization of sustainable development in neighbourhoods is the initial step towards sustainable development at higher levels.

Therefore, it can be stated that the use of certification systems and the results of sustainability assessment is significant for all the people and groups in an urban zone. The figure below introduces these groups (so-called community stakeholders):

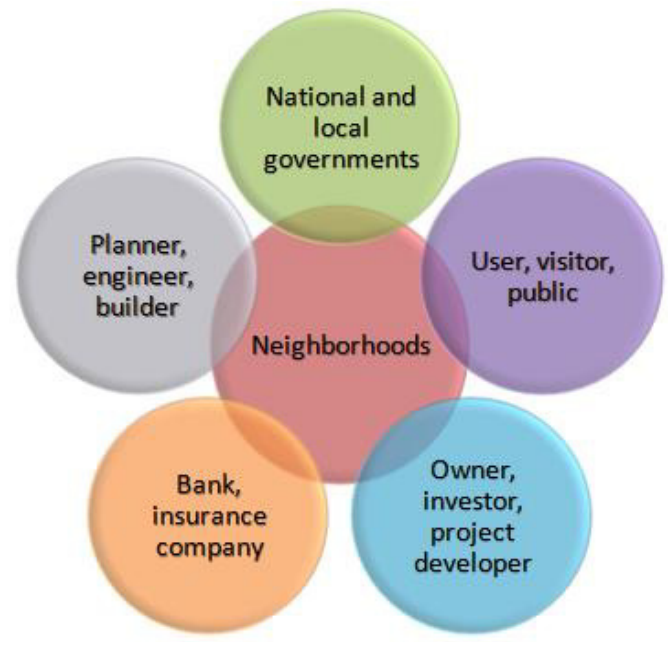

Figure 2: $\quad$ Urban development stakeholders [3].

\subsection{National/international certification systems}

In this section, three important certification systems which have been offered for sustainability assessment in neighbourhoods will be introduced. The selected certification systems are:

BREEAM - Communities: the understanding of this is important; as this is the oldest and one of the most used certification tools.

LEED - ND: the understanding of this is important; as this is the most famous and widely applicable. 
DGNB - NSQ: the understanding of this is important; as this are one of the newest certificates and the first one from Germany (the most industrial European country and the most active in the construction and development of sustainable cities). The information about each certification system is categorized in table 1 .

It is worth mentioning that there are some other certification tools besides these three certification systems, as seen in the following table:

Table 1: $\quad$ The famous certification tools.

\begin{tabular}{|c|c|c|c|}
\hline Certification Tool & Year & Country & $\begin{array}{c}\text { Certification for urban } \\
\text { communities }\end{array}$ \\
\hline BREEAM & 1990 & UK & BREEAM - Communities \\
\hline HQE & 1996 & France & HQE - Aménagement \\
\hline LEED & 1998 & USA & LEED - ND \\
\hline CASBEE & 2001 & Japan & CASBEE - UD \\
\hline Green Star & 2002 & Australia & Green Star - Communities \\
\hline DGNB & 2009 & Germany & DGNB - NSQ \\
\hline
\end{tabular}

\section{A comparison between certification systems}

This section is dedicated to the comparison and evaluation of certification tools. For this purpose, the following certification systems will be compared: BREEAM Communities, LEED-ND, and DGNB-NSQ. It is worth mentioning that this comparison does not mean to select the best certification system or recommend one of these three to be applied as a global standard; on the contrary, it intends to study and compare the features of these certification tools in order to indicate the advantages, disadvantages, and the unique features of each.

Table 2 shows the overall characteristics of these three certification systems.

Table 2: $\quad$ An overview of three certification systems [4].

\begin{tabular}{|c|c|c|c|}
\hline & BREEAM Communities & LEED - ND & DGNB - NSQ \\
\hline Title & $\begin{array}{c}\text { Building Research } \\
\text { Establishment } \\
\text { Environmental } \\
\text { Assessment Method (for) } \\
\text { Communities }\end{array}$ & $\begin{array}{l}\text { Leadership in } \\
\text { Energy and } \\
\text { Environment } \\
\text { Design - } \\
\text { Neighborhood } \\
\text { Development }\end{array}$ & $\begin{array}{c}\text { German Sustainable } \\
\text { Building Council - } \\
\text { New City Districts } \\
\text { (Deutsche } \\
\text { Gesellschaft für } \\
\text { Nachhaltiges Bauen - } \\
\text { Neubau } \\
\text { Stadtquartiere) }\end{array}$ \\
\hline Logo & & & \\
\hline
\end{tabular}


Table 2: $\quad$ Continued.

\begin{tabular}{|c|c|c|c|}
\hline Developer & $\begin{array}{l}\text { Building Research } \\
\text { Establishment } \\
\text { (BRE) }\end{array}$ & $\begin{array}{l}\text { U.S. Green } \\
\text { Building Council } \\
\text { (USGBC) }\end{array}$ & $\begin{array}{c}\text { German } \\
\text { Sustainable } \\
\text { Building Council } \\
\text { (DGNB) }\end{array}$ \\
\hline $\begin{array}{l}\text { Country of } \\
\text { origin }\end{array}$ & United Kingdom & $\begin{array}{c}\text { United States of } \\
\text { America }\end{array}$ & Germany \\
\hline Release & 2009 & 2009 & 2011 \\
\hline $\begin{array}{l}\text { Groups of } \\
\text { Criteria }\end{array}$ & $\begin{array}{c}\text { - Climate \& Energy } \\
\text { - Resources } \\
\text { - Place Shaping } \\
\text { - Transport \& } \\
\text { Movement } \\
\text { - Community } \\
\text { - Ecology \& } \\
\text { Biodiversity } \\
\text { - Business \& } \\
\text { Economy } \\
\text { - Buildings }\end{array}$ & $\begin{array}{c}\text {-Smart Location \& } \\
\text { Linkage } \\
\text { - Neighborhoods } \\
\text { Pattern \& Design } \\
\text { - Green } \\
\text { Infrastructure \& } \\
\text { Buildings } \\
\text { - Innovation \& } \\
\text { Design Process } \\
\text { - Regional Priority } \\
\text { Credits }\end{array}$ & $\begin{array}{c}\text { - Ecological } \\
\text { Quality } \\
\text { - Economical } \\
\text { Quality } \\
\text { - Sociocultural } \\
\text { \& Functional } \\
\text { Quality } \\
\text { - Technical } \\
\text { Quality } \\
\text { - Process Quality }\end{array}$ \\
\hline $\begin{array}{l}\text { Rating } \\
\text { System }\end{array}$ & $\begin{array}{c}\text { Outstanding } \\
\text { Excellent } \\
\text { Very Good } \\
\text { Good } \\
\text { Pass }\end{array}$ & $\begin{array}{c}\text { Platinum } \\
\text { Gold } \\
\text { Silver } \\
\text { Bronze }\end{array}$ & $\begin{array}{l}\text { Gold } \\
\text { Silver } \\
\text { Bronze }\end{array}$ \\
\hline $\begin{array}{l}\text { Certification } \\
\text { phases }\end{array}$ & $\begin{array}{l}\text { - Planning } \\
\text { - Project completion }\end{array}$ & $\begin{array}{l}\text { - Planning } \\
\text { - Construction } \\
\text { - Project } \\
\text { completion }\end{array}$ & $\begin{array}{l}\text { - Planning } \\
\text { - Construction } \\
\text { - Project } \\
\text { completion }\end{array}$ \\
\hline $\begin{array}{l}\text { Certification } \\
\text { Institute }\end{array}$ & $\begin{array}{l}\text { Building Research } \\
\text { Establishment } \\
\text { (BRE) Global }\end{array}$ & $\begin{array}{l}\text { Green Building } \\
\text { Certification } \\
\text { Institute (GBCI) }\end{array}$ & $\begin{array}{c}\text { German } \\
\text { Sustainable } \\
\text { Building Council } \\
\text { (DGNB) }\end{array}$ \\
\hline $\begin{array}{l}\text { Assessment } \\
\text { Method }\end{array}$ & $\begin{array}{l}\text { Third-party, } \\
\text { Education and } \\
\text { Accreditation } \\
\text { through BRE Global }\end{array}$ & $\begin{array}{l}\text { Third-party, } \\
\text { Education and } \\
\text { Accreditation } \\
\text { through GBCI }\end{array}$ & $\begin{array}{l}\text { Third-party, } \\
\text { Education and } \\
\text { Accreditation } \\
\text { through DGNB }\end{array}$ \\
\hline $\begin{array}{l}\text { Certified } \\
\text { Projects }\end{array}$ & - & $\begin{array}{c}100 \text { registered, } 2 \\
\text { certified } \\
(2011.08 .30)\end{array}$ & - \\
\hline Website & www.breeam.org & www.usgbc.org & www.dgnb.de \\
\hline
\end{tabular}

Various factors can be applied to compare certification systems. Here, certification tools are compared and evaluated based on rating system, certification process, and criteria. 


\subsection{Rating system}

As far as rating system is concerned, three major differences can be noticed between certification systems.

The first difference is related to the weight that each criterion has for scoring. In DGNB, this weight, which is indicative of the significance of each criterion, is considered 1 to 3 for each criterion. Each main group also has a weight (DGNB has 5 main groups); for the existing main groups, this weight equals $22.5 \%$ (except the process quality which has the weight of 10\%). In BEEAM, not only are the weights of criteria different, they also vary based on different locations the nine English Regions (in general, the weight is considered between 0.5 and 1.0). Apart from this, the main groups don't have a specific weight (BREEAM has 8 main groups). LEED rating system is mostly similar to BREEAM in that the criteria have different weights based on their importance. However, main groups don't have specific weights individually; in fact, the number and weight of the existing criteria in each group determine its weight. In the figure 3 , the main groups and their importance are shown for each certification system.

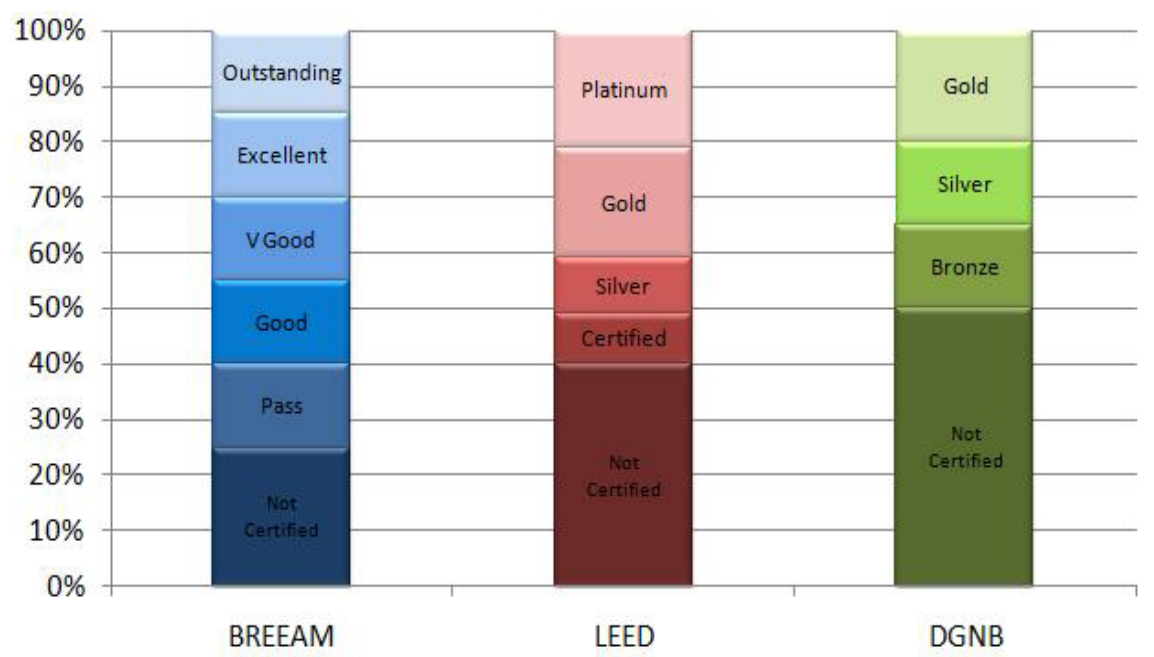

Figure 3: A comparison between BREEAM, LEED, and DGNB rating level.

The second difference is in the "minimum gained score". This issue is defined as pre-requirements in LEED, and as mandatory credits in BREEAM; it means that some of the criteria are mandatory and gaining the minimum score in them is necessary in all projects. This ensures the existence of some fundamental elements in the project. There are no mandatory criteria in DGNB; the minimum gained score is considered in each main group. The final rating of the project depends on the final gained score as well as this factor. As a result, a minimum quality level is guaranteed for all the elements of the project. 
The third and last difference in rating systems of the certification tools is related to different rating levels. The following figure shows the rating levels for BREEAM, LEED, and DGNB:

According to the figure 3 , DGNB is generally the strictest about certifying projects, and then comes LEED and finally BREEAM. However, BREEAM uses the most labels for certification; and ranking highest (outstanding for which special requirements are presented) in it is much more difficult than ranking highest in other certification systems (gold for DGNB; platinum for LEED).

Overall, LEED utilizes a simpler rating system than the other two certification systems; BREEAM stands in the middle and finally DGNB has the most complex and strict rating system.

\subsection{Certification process}

In general, in the steps required for certification there are no fundamental differences between the three certification tools. In other words, the rating process begins with registering the project. The documents required for assessment are completed and submitted to the corresponding certification institute. After criteria examination and rating, the certificate is issued. The assessment method, which is in the form of third-party assessment, is similar in these three systems; the only mentionable difference is in LEED, which does not necessitate a trained professional for completing, examining and submitting the documents. On the other hand, the use of LEED Accredited Professional (AP) is considered a merit for the project.

They are briefly shown for each of these certification systems in the following table:

Table 3: A comparison between BREEAM, LEED, and DGNB certification process [5-7].

\begin{tabular}{|c|c|c|}
\hline BREEAM Communities & LEED-ND & DGNB-NSQ \\
\hline - Interim Certificate & - Conditional & Pre Certificate : Planning \\
(optional) : planning stage & Approval of Plan & - Certificate : \\
- Final Certificate : post & - Pre Certificate & Exploitation \\
construction stage & - Certificate : post & - Certificate : Quarter, \\
& construction stage & Post construction \\
\hline
\end{tabular}

\subsection{Criteria}

The criteria in each certification system have been explained in figures 4, 5 and 6 in general, in detail. However, similar benchmarks and subjects should be used for the comparison between certification systems. Therefore, the criteria and existing groups in BREEAM Communities, LEED-ND, and DGNB-NSQ along 


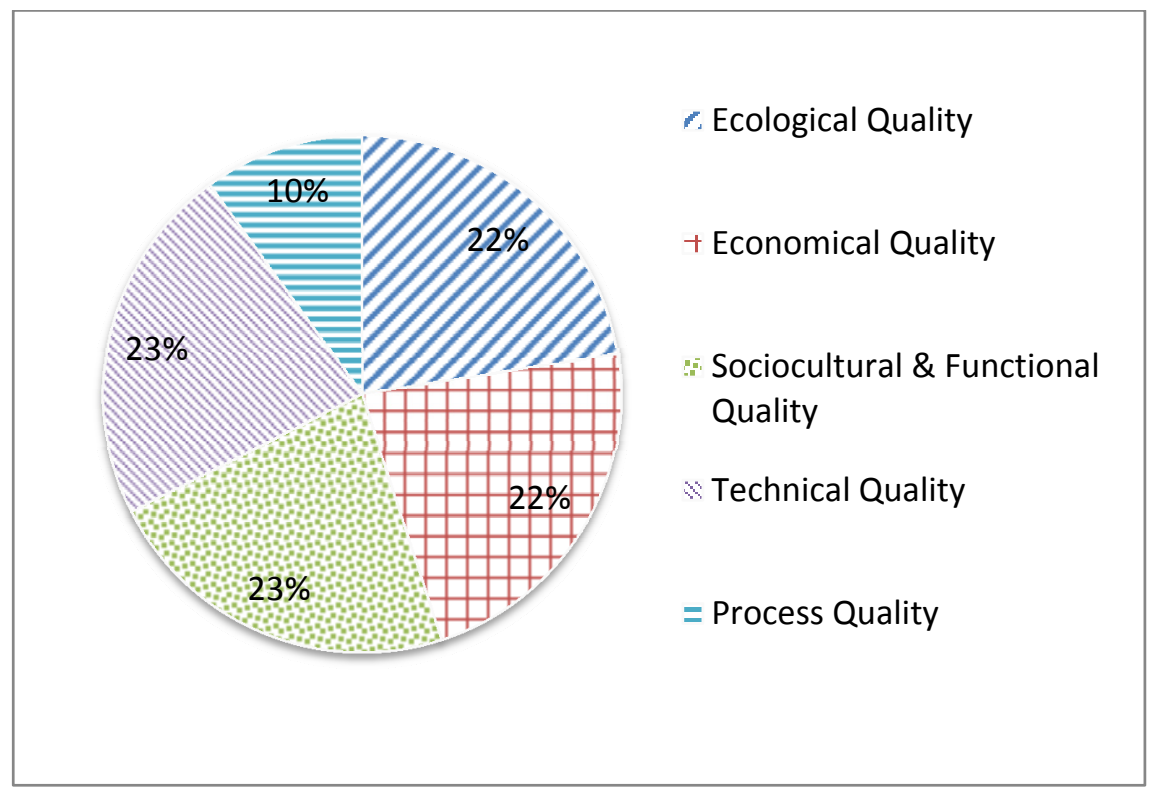

Figure 4: $\quad$ DGNB main groups of criteria.

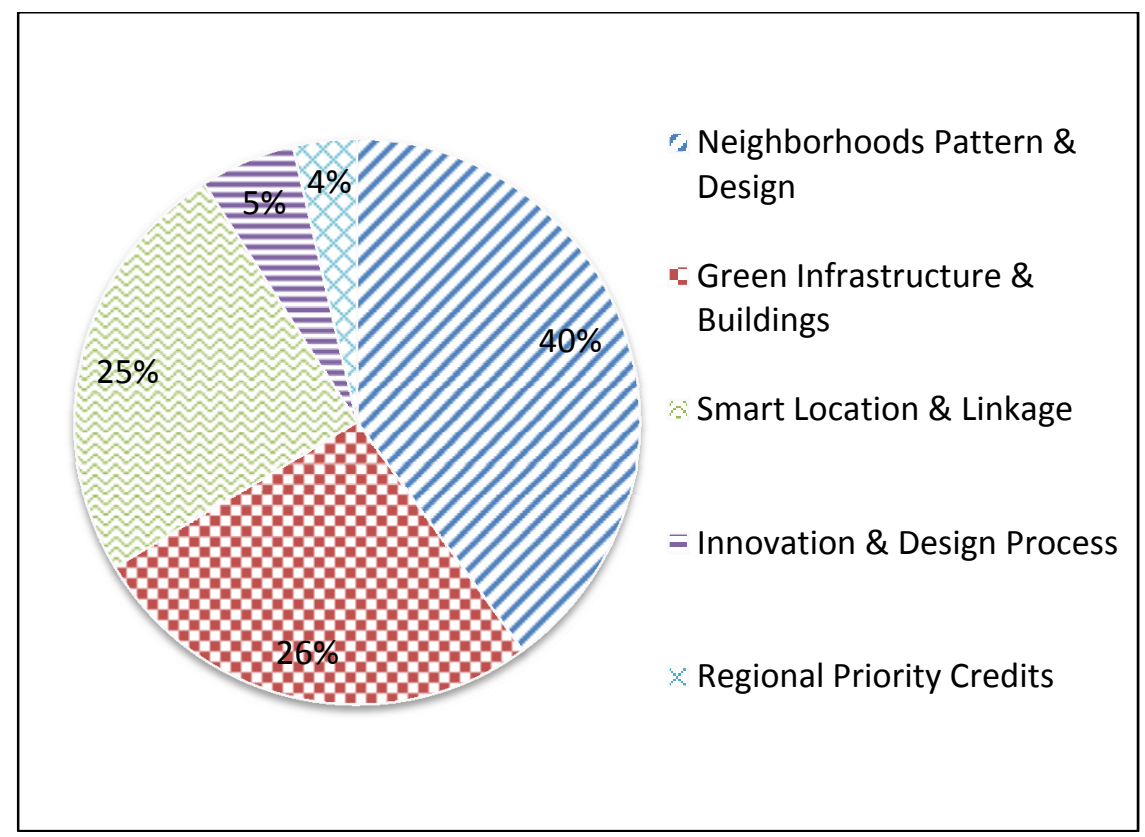

Figure 5: LEED main groups of criteria. 


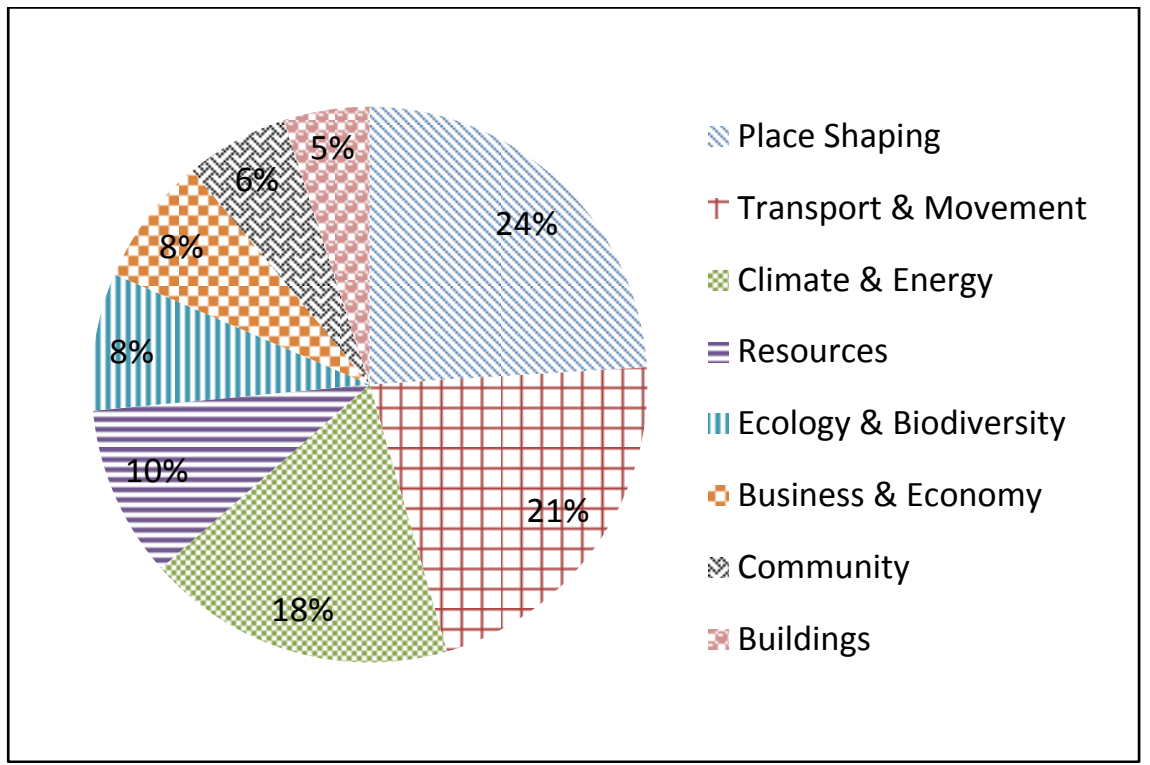

Figure 6: BREEAM main groups of criteria.

with the main criteria of sustainability assessment for neighbourhoods has been studied and 13 main groups as well as 42 benchmarks for the comparison of these three certification systems are identified. The result is shown in the following figure 7 .

According to figure 7 , some of the subjects receive more attention in one more than in the other two. These subjects are as follows:

BREEAM Communities: Transportation, Resources efficient use.

LEED-ND: Location of new community and existing communities, Design and planning.

DGNB-NSQ: Business and economy, Process and construction management.

Overall, studying the criteria and indicators in each certification system results in the following key points:

DGNB pays more attention to the cohesion of sustainable development aspects (environmental, economic, and social) than the other two certification tools.

LEED criteria are most compatible with the common plans and elements of urban planning and criteria assessment in projects is simply possible in practice.

BREEAM pays the most attention and is yet most dependent on the environmental conditions and characteristics of each project. 


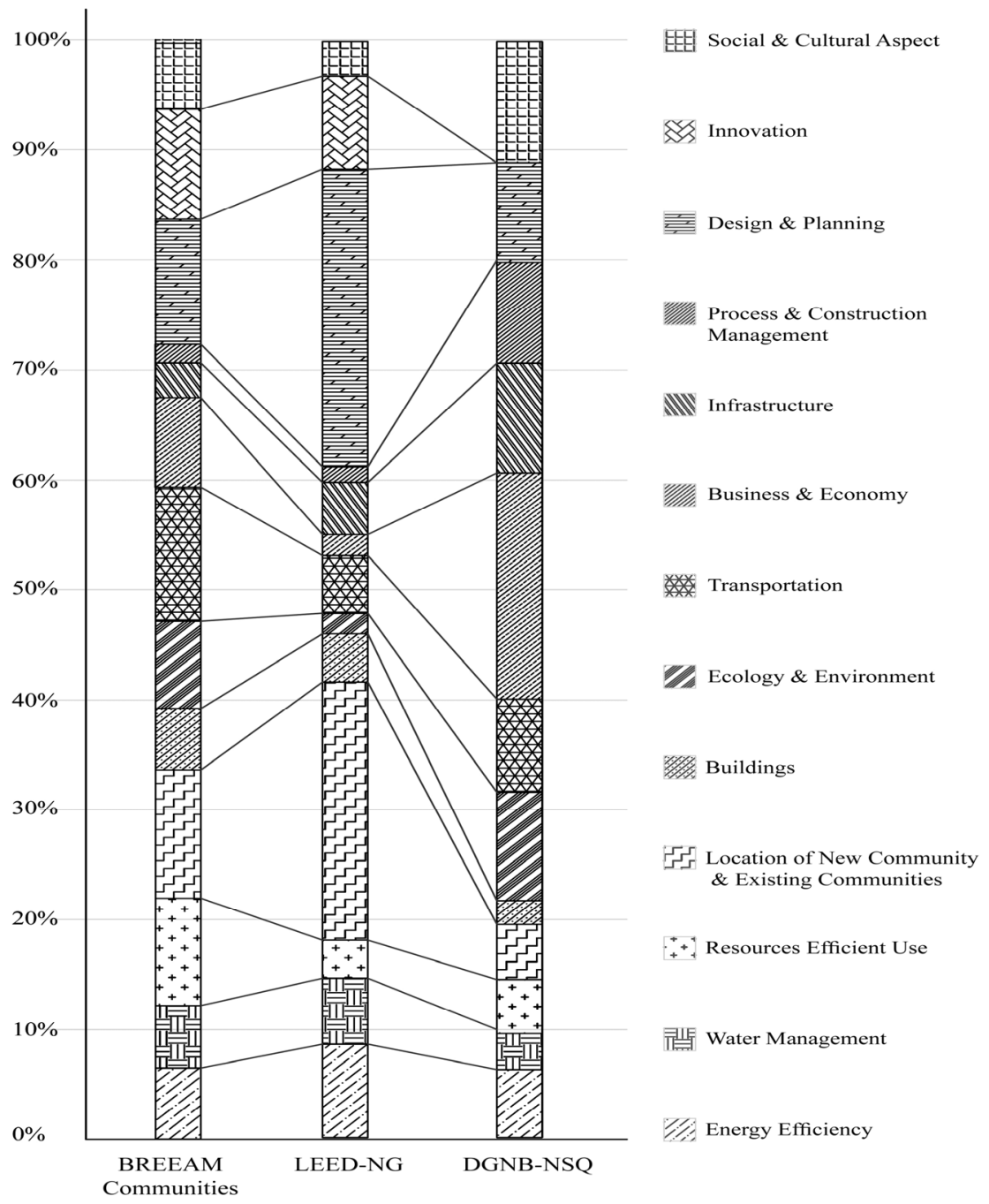

Figure 7: A comparison between BREEAM, LEED, and DGNB criteria.

\section{Conclusion}

According to the result of the above comparison, certification systems are of great significance at international levels and play a key role in the whole development of sustainability. This raises a basic question as to what necessary steps must be taken for adaption and development, and more generally, to prepare a certification system. The adaption process of BREEAM, LEED, and DGNB certification systems, along with national GBC's experiences is as follows: 
Understanding the current condition, Establishing local organizations and governmental or non-governmental departments, Developing legal mechanisms completing and improving standards, Acknowledgement and training, Creating or completing databases, Preparing technical documentation, Offering an adapted certification system, Pilot phase and Monitoring system.

It can be concluded that identifying comprehensive objectives, adopting proper strategies to realize those objectives, applying certification systems to control the performed activities, and correcting the objectives and strategies will definitely guarantee sustainable development achievements.

\section{References}

[1] OECD (2001) The DAC Guidelines, Strategies for sustainable development. OECD Publication service, France, (http://www.oecd.org/dataoecd/34/10 /2669958.pdf,2011.08.05), p. 25,41(2011)

[2] Pahl-Weber, Elke and Bodenschatz, Harald, DV. Kommission Zertifizierung in der Stadtentwicklung, Bericht und Perspektive (http://www.deutscher verband.org/cms/fileadmin/medias/Stichworte/PDFs/Zertifizierungsbericht.p df, 2011.06.23). p.15,.31(2011)

[3] Lützkendorf, Thomas and Speer, Thorsten etc., A comparison of international classification for performance requirements and building performance categories used in evaluation methods. p. 7(2010)

[4] BREEAM (http://www.breeam.org/), LEED (http://www.usgbc.org /DisplayPage.aspx?CategoryID=19), DGNB (http://www.dgnb.de/_de/). Also Cf. Heyder, Monika and Koch, Andreas (2011) Nachhaltigkeitszertifizierung von Stadtquartieren als Beitrag zur Nachhaltigen Entwicklung.

[5] GBCI, LEED for ND (http://www.gbci.org/main-nav/buildingcertification/certification-guide/leed-for-neighborhooddevelopment/about.aspx,2011.08.06),

[6] DGNB (2011) DGNB Zertifizierungssystem neubau Stadtquartiere (https://www.sebassetmanagement.de/fileadmin/data_archive/PDF_Publikat ionen/110621_DGNB_Stadtquartiere_BerlinPotsdamerPlatz.pdf, 2011.07.05) pp. 12-17 (2011)

[7] BRE Global (2011) BREEAM for Communities: Stage 2. Technical Guidance Manual. (http://www.breeam.org/filelibrary/BREEAM \%20Communities/BREEAM_Communities_Stage_2_Version_1_280211v1. pdf,2011.07.15) p. $22(2011)$ 